\title{
Clinical presentations and molecular basis of complement C1R mutation in a large turkish family
}

\author{
Erkan Demirkaya ${ }^{1 *}$, Ozgur Kasapcopur ${ }^{2}$, Kenan Barut $^{3}$, Salim Caliskan $^{3}$, Adem Polat $^{4}$, Yesim Onen ${ }^{4}$, \\ Ivona Aksentijevich ${ }^{1}$
}

From 21st European Pediatric Rheumatology (PReS) Congress

Belgrade, Serbia. 17-21 September 2014

\section{Introduction}

Inherited deficiencies of complement components can result in autoimmunity. Early age of onset, prominent cutaneous manifestations, and presence of anti-Ro antibodies are features suggestive of a complement deficiency. SLE-associated deficiencies in subcomponents of the $\mathrm{C} 1$ complex, $\mathrm{C} 1 \mathrm{r}$ and/or $\mathrm{C} 1 \mathrm{~s}$, were described 4 decades ago, however the molecular basis and functional aspects of the complement deficiency have not been clearly determined.

\section{Objectives}

The aim of this study was to identify the cause of presumably recessively inherited form of SLE and/or lupus-like syndrome (LLS) in a consanguineous family from Turkey.

\section{Methods}

We studied 2 pairs of young female siblings(4 patients), who presented with Lupus-like syndrome but with a significant phenotypic variability and differences in the disease severity. They shared a history of episodes of malar and/or generalized rash and ANA positivity, while anti-dsDNA were negative in all four. Renal involvement was prominent in one pair of siblings and one patient developed CNS manifestations including convulsion.

DNA samples from the affected patients, their unaffected parents and siblings were isolated from whole blood. We performed whole-exome sequencing in 9 samples from this family and Sanger sequencing in other family members.

IInflammatory Disease Section, National Human Genome Research Institute, Bethesda, USA

Full list of author information is available at the end of the article

\section{Results}

We identified a homozygous frameshift mutation in the CR1 gene (NM_001733.4;c.1331delT; p.Pro445Leufs"11), encoding complement $1 \mathrm{r}$ subunit, in all 4 affected siblings. The homozygous p.Pro445Leufs*11 mutation was validated with Sanger sequencing in all four patients while their unaffected parents and siblings were either heterozygous carriers or non-carriers. One 9y old sibling was identified as homozygous for the mutation but is yet unaffected. Despite the same genotype the affected patients have variable phenotypes concerning disease features, severity, disease outcome, thus suggesting a role for other modifying alleles or epigenetic factors.

\section{Conclusion}

Our findings show the second molecular evidence that loss-of-function mutations in C1R are the cause of SLE or lupus-like syndrome. We report a novel genetic defect in the $\mathrm{C} 1 \mathrm{r}$ complement protein leading to a recessive form of familial SLE/LLS in the Turkish population. This mutation is likely present in the general population and it should be included in diagnostic evaluation of Turkish patients with early onset SLE.

We plan extensive biochemical, immunologic, and functional assays to assess the impact of this pathogenic mutation on complement function, apoptosis, neutrophil and B cell biology.

\section{Disclosure of interest}

None declared.

\section{Authors' details}

${ }^{1}$ Inflammatory Disease Section, National Human Genome Research Institute, Bethesda, USA. ²Pedaitric Rheumatology, İstanbul University, Cerrahpasa 
Medical Faculty, İstanbul Turkey, Istanbul, USA. ${ }^{3}$ Pedaitric Rheumatology, İstanbul University, Cerrahpasa Medical Faculty, İstanbul Turkey, Istanbul, Turkey. ${ }^{4}$ FMF Arthritis Vasculitis and Orphan disease Research in pediatric rheumatology (FAVOR), Gulhane Military Medical Academy, Ankara, Turkey.

Published: 17 September 2014

doi:10.1186/1546-0096-12-S1-P116

Cite this article as: Demirkaya et al.: Clinical presentations and molecular basis of complement C1R mutation in a large turkish family. Pediatric Rheumatology 2014 12(Suppl 1):P116.

Submit your next manuscript to BioMed Central and take full advantage of:

- Convenient online submission

- Thorough peer review

- No space constraints or color figure charges

- Immediate publication on acceptance

- Inclusion in PubMed, CAS, Scopus and Google Scholar

- Research which is freely available for redistribution

Submit your manuscript at www.biomedcentral.com/submit 